UDC 579.222:579.841.1

DOI: 10.15587/2519-8025.2020.205217

\title{
QUORUM SENSING AUTOINDUCERS BIOSYNTHESIS BY BIOFILM CULTURES OF PSEUDOMONAS AERUGINOSA STRAINS WITH DIFFERENT LEVELS OF THE CYCLIC DIGUANOZINMONOPHOSPHATE
}

\author{
M. Galkin, A. Semenets, B. Galkin, T. Filipova
}

\begin{abstract}
Мета роботи - встановити залежність між вмістом ичикло-ди-ГМФ $і$ здатністю Р. aеruginosa до утворення біоплівки і синтезу аутоіндукторів системи кворуму.

Матеріали та методи дослідження. В роботі були використані итам дикого типу Р. aеruginosa PA01 i штами P. aeruginosa з низьким (PAO1pJN2133) та підвищеним (РA01 АwspF) рівнями циклічного дигуанозинмонофосфату. Культивування проводили у24-лункових плоскодонних планшетах Nисlоп при $37{ }^{\circ} \mathrm{C} y$ середовищі LB. Масу біоплівки визначали у CV-тесті. Вимірювання здійснювали на спектрофотометрі SmartSpecPlus (Bio-Rad, Hungary) при довжині хвилі 592 нм. Аиил-гомсеринлактони екстрагували підкисленим етилацетатом та визначали їх кількість методом ГХ/МС. Визначення вмісту циикло-ди-ГМФ проводили з використанням репортерної плазміни Sеattle шляхом вимірювання інтенсивності флуоресценціі клітин у біоплівках.

Результати дослідження. Встановлено, щзо итам Р. aeruginosa PA01 pJN2133, внутрішньоклітинний вміст ичикло-ди-ГМФ якого є у 4 рази меншим ніж у P. aeruginosa, утворює біоплівку, маса якої у 3,5 рази нижча ніж у батьківського штаму. Штам P. aeruginosa PA01 DwspF перевищує P. aeruginosa PA01 за иими показниками у 1,5 рази та 33 \%, відповідно. Ще більш виражені відмінності виявляються при співставленні між собою мутантних итамів. За рівнем ичикло-ди-ГМФ Р. aeruginosa PA01 $\Delta w s p F$ переважає штам РА01 рJN2133 у 5,9 рази, а за масою біоплівки - у п'ять разів. Найбільшу кількість сигнальних молекул системи кворум сенсінг синтезує штам з низьким рівнем вторинного месенджера.

Висновки. Між внутрішньоклітинним вмістом иикло-ди-ГМФ $і$ здатністю до утворення біоплівки існує прямо-пропориійна залежність:чим вище вміст вторинного месенджера, тим більша маса біоплівки. Концентрація аутоіндукторів QS у середовищі зворотнім чином зв'язана з внутрішньоклітинним вмістом иикло-ди-ГМФ: у порівнянні з батьківським штамом підвищена у итаму з низьким вмістом вторинного месенджера $і$ знижена у штаму з його підвищеним рівнем
\end{abstract}

Ключові слова: Pseudomonas aeruginosa, quorum sensing, біоплівки, ичикло-ди-ГМФ, аутоіндуктори QS

Copyright (C) 2020, M. Galkin, A. Semenets, B. Galkin, T. Filipova. This is an open access article under the CC BY license (http://creativecommons.org/licenses/by/4.0).

\section{Introduction}

Pseudomonas aeruginosa is a widespread microorganism, can colonize numerous ecological niche and cause opportunistic infections in humans. Such properties are related to its ability to form biofilms and produce various pathogenic factors $[1,2]$. The process of biofilm development consists of three key stages: adhesion to any surface and the transition from a mobile to a sedentary lifestyle; growth of microcolonies, maturation of a biofilm and differentiation of its cells; destruction of the biofilm and resettlement of cells for colonization of new areas. The life cycle of biofilms is controlled by two signalling systems - the intercellular communication system (quorum sensing, QS) and cyclic diguanosine monophosphate (cyclic-di-GMP). Separately, both systems have been studied in depth, but studies of their interaction have begun recently. Therefore, there are many unresolved issues that need further study [3].

\section{Literary review}

Cyclic-di-GMP is an intracellular secondary messenger that coordinates the transition of bacteria from a mobile to an attached state $[4,5]$. It was found that in many species of bacteria the concentration of cyclic-diGMP in biofilm cells is much higher than in freely existing ones [6]. Thus, it is shown that $P$. aeruginosa in the biofilm contains an average of 75-110 pmol cyclicdi-GMP per mg of total cell extract, while planktonic cells contain $<30 \mathrm{pmol} / \mathrm{mg}$. It is assumed that bacterial cells use cyclic-di-GMP to control the development of the biofilm and the change in its concentration is a signal for the transition of the biofilm from one stage to another [7]. The level of the secondary messenger in the cell depends on the rates of its synthesis and decay. The cyclic-di-GMP molecule is synthesized from two GTP molecules by enzymes called diganylate cyclase (DGC) and degrades to 5'-phosphoguanylyl-(3'-5')phosphogua nosine (pGpG) and / or GMP by phosphodiesterase (PDE). These enzymes come in multiple forms and are usually associated with a variety of PerArnt-Sim (PAS) sensory domains, allowing the cell to receive numerous internal and external signals. The genome of $P$. aeruginosa $\mathrm{PAO} 1$ encodes 41 proteins involved in cyclic-di-GMP metabolism [8]. Due to this, this sec- 
ondary messenger is involved in numerous cellular functions, including cell cycle regulation, differentiation, biofilm formation and dispersion, motility and virulence [9].

Quorum sensing (QS) is a mechanism that is activated in response to cell density and used by many bacteria to coordinate gene transcription. In QS, bacteria constitutively express signalling molecules called autoinducers. When the concentrations of QS molecules reach the threshold, they bind to certain bacterial receptors and trigger a coordinated program of increased transcription of bacterial virulence genes. This mechanism is particularly important for the expression of pathogenicity in $P$. aeruginosa. Two interconnected units of QS P. aeruginosa use acyl-homoserine lactone signalling molecules: Las and Rhl systems [10, 11]. LasI synthase is responsible for synthesis $\mathrm{N}$-(3-oxododecanoyl)-L-homoserine lactone (3-oxo-C12-HSL), which is recognized by the LasR receptor. The Rhl system uses N-butanoylhomoserine lactone (C4-HSL) produced by RhlI synthase and bound to the RhlR receptor [12]. The third, the Pqs system, uses the signal quinolone specific to $P$. aeruginosa: 2-heptyl-3-hydroxy-4-quinolone (PQS), and interacts closely with the Las and Rhl units [13]. The most important functional effect of QS activation is the formation of a biofilm, which provides benefits for the survival of bacteria in any ecosystem. A study of the Lasdeficient strain of $P$. aeruginosa showed that it forms an undeveloped biofilm that does not contain classical multicellular fungal-like structures. These data suggest that the QS system is not absolutely necessary for the formation of biofilms, but it is responsible for the development of mature biofilms. This is supported by the presence of fungal-like structures of eDNA and rhamnolipids, the synthesis of which is under the control of the QS system [14, 15].

Thus, according to the literature, we can conclude that both signalling systems are necessary for bacteria to form a full-fledged biofilm, which indicates the relevance of in-depth study of their interaction.

\section{The purpose and objectives of the study}

The aim of the work is to establish the relationship between the content of cyclic-di-GMP and the ability of $P$. aeruginosa to form a biofilm and the synthesis of autoinducers of the quorum system.

Research objectives:

1. To establish the relationship between the content of cyclic-di-GMP and the mass of the formed biofilm of the $P$. aeruginosa studied strains.

2 . To investigate the level of biosynthesis of autoinducers of QS by biofilm cultures of the P. aeruginosa studied strains.

\section{Materials and methods of the research}

The wild-type strain of $P$. aeruginosa PA01 from the collection of cultures of the Department of Microbiology, Virology and Biotechnology of ONU named after I.I. Mechnikov and strains of $P$. aeruginosa with low (PAO1 pJN2133) and elevated (PA01 $\Delta w s p F$ ) levels of cyclic diguanosine monophosphate were used provided by O. Rzhepishevska from the University of Umeå, Sweden. The work was performed in 2018-2019.
Cultivation was performed in 24-well flatbottomed plates Nuclon at $37^{\circ} \mathrm{C}$ LB medium with the following composition (g/l): peptone - 15.0, yeast extract -10.0 , sodium chloride -5.0 .

Each well was assigned 8 wells: four to determine the mass of the biofilm and four - the number of cells in the biofilm. The mass of the biofilm was determined using the CV test [16]. Measurements were performed on a spectrophotometer Smart Spec Plus (Bio-Rad, Hungary) at a wavelength of $592 \mathrm{~nm}$.

To determine the number of cells, the biofilms were removed from the bottom of the wells with a soft plastic spatula, saline (PS) was added, and the cells were homogenized and precipitate by centrifugation. The pellet was suspended in $1 \mathrm{ml}$ of PS and the number of cells was determined spectrophotometrically.

The liquid taken from the wells was centrifuged to remove planktonic cells and the autoinducers were extracted three times from the supernatant with acidified ethyl acetate. The content of acyl-homserinlactones was determined by GC/MS using chromato-mass spectrometric system Agilent 6890N / 5973 inert [17], signal quinolone - by HPLC on a liquid chromatograph Agilent 1260 Infinity II [18]. Commercial samples of SIGMAALDRICH autoinducers were used as standards.

Determination of cyclic-di-GMP content was performed using the Seattle reporter plasmid (pMH487 (pCdrA:gfpS)) according to the method [19]. Before introducing the plasmid into the cells, they were electroporated on a Bio-Rad MicroPulser, 1.6-2.5 kV, $25 \mu \mathrm{F}$, 200 omega. After two hours of incubation with the plasmid, the cells were washed and transferred to 96-well black Costar plates. After $24 \mathrm{~h}$ of cultivation at $37^{\circ} \mathrm{C}$, the culture fluid was removed, the biofilms were washed with phosphate buffer and the fluorescence was measured in relative units (extinction $\lambda 485 \mathrm{~nm}$, emission $\lambda 535 \mathrm{~nm}, \lambda_{\mathrm{OD}} 595 \mathrm{~nm}$ ) on a Tecan GENios plate reader. After measuring the fluorescence intensity, the number of cells in the biofilms was determined and the relative values for each strain were calculated.

All experiments were performed in three independent experiments with 3-4 replicates in each.

Statistical processing of research results was carried out using conventional methods of variation analysis. The average values of the indicators $\left(\mathrm{X}^{-}\right)$and their standard error (SX S) were calculated. Significance of differences between means was determined by Student's criterion, assessing the reliability of the results at a significance level of at least $95 \%(\mathrm{p} \leq 0.05)$. Mathematical calculations were performed using the computer program Excel [20].

\section{The results of the study}

Used in the work of $P$. aeruginosa strains with low (PA01 pJN2133) and high (PA01 $\Delta w s p F)$ relative to the parent strain content of cyclic-di-GMP were constructed in the laboratory of Caroline S. Harwood [9]. The level of cyclic-di-GMP in cells depends on the activity of two specific enzymes - diguanylate synthase (WspR) and cyclo-diguanylate phosphodiesterase (protein PA2133). Depletion of the secondary messenger level in $P$. aeruginosa pJN2133 is achieved by additional copies of the PA2133 gene introduced into 
cells as part of plasmid pJN105 (empty vector). Mutation in the $w s p F$ gene, the product of which is a negative regulator of diguanylate synthase, contributes to the increase in cyclic-di-GMP levels in $P$. aeruginosa $\Delta w s p F$.

Given that the increase in cyclic-di-GMP levels is a signal for the transition of bacterial cells from free to attached [4], we have previously studied the architecture of biofilms formed by the studied strains of $P$. aerugino$s a$ [21]. Significant differences in their general appearance and structure were found between strains of $P . a e$ ruginosa PA01 and $P$. aeruginosa PA01 $\Delta w s p F$, on the one hand, and strain $P$. aeruginosa PA01 pJN2133, on the other. According to light and laser confocal microscopy, multicellular three-dimensional structures were present in $P$. aeruginosa PA01 and PA01 $\Delta w s p F$ biofilms, while $P$. aeruginosa PA01 pJN2133 biofilm did not contain such formations and appeared "monolayer". In addition, in the biofilm of strain PA01 pJN2133 its components: cells and extracellular matrix, were evenly distributed on the surface.

Quantitative characteristics of biofilms of the studied strains and their content of cyclic-di-GMP are shown in Fig. 1.

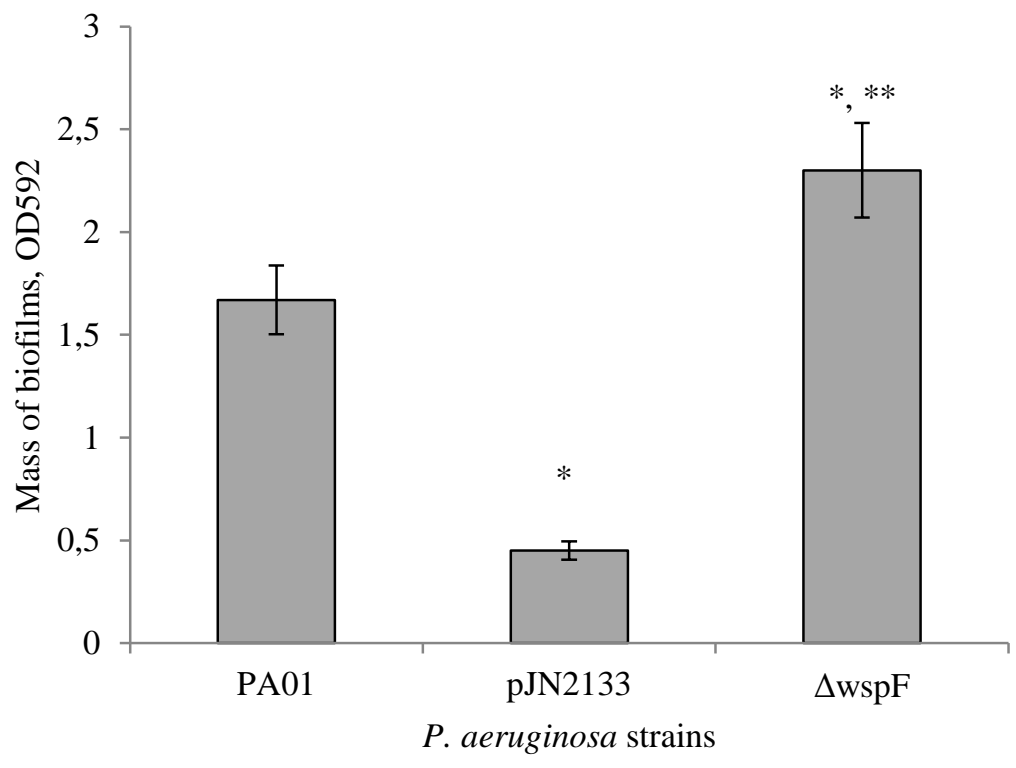

$a$

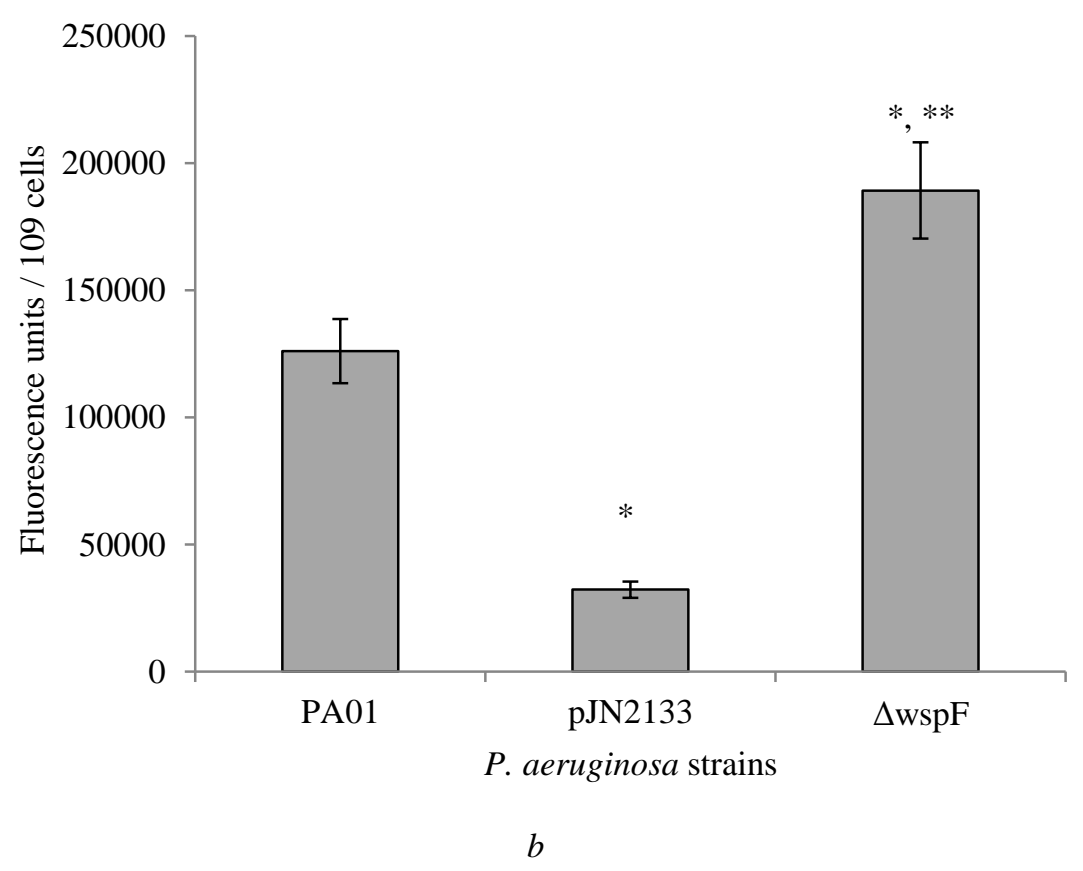

Fig. 1. The relationship between the content of cyclic-di-GMP and the mass of biofilms of the studied strains of $P$. aeruginosa:

$a$ - mass of biofilms; $b$ - the content of cyclic-di-GMP in biofilm cells;

* - the difference is significant in comparison with strain PA01 $(\mathrm{p} \leq 0.01)$;

** - the difference is significant compared to strain $\mathrm{pJN} 2133(\mathrm{p} \leq 0.001)$ 
The obtained results revealed a direct dependence of the mass of biofilms on the level of the secondary messenger in its cells. Thus, the strain of $P$. aeruginosa PA01 pJN2133, the intracellular content of cyclic-diGMP which is 4 times less than that of $P$. aeruginosa, forms a biofilm, the mass of which is 3.5 times lower than that of the parent strain. The strain of $P$. aeruginosa PA01 $\Delta w s p F$ exceeds P. aeruginosa PA01 by 1.5 times and $33 \%$, respectively. Even more pronounced differences are found when comparing mutant strains. The cyclic-di-GMP level of $P$. aeruginosa PA01 $\Delta w s p F$ is 5.9 times higher than the PA01 pJN2133 strain, and the biofilm weight is five times higher.

Presented in Fig. 2 data show opposite to the content of the secondary messenger changes in the levels of autoinducers of the quorum sensing system.

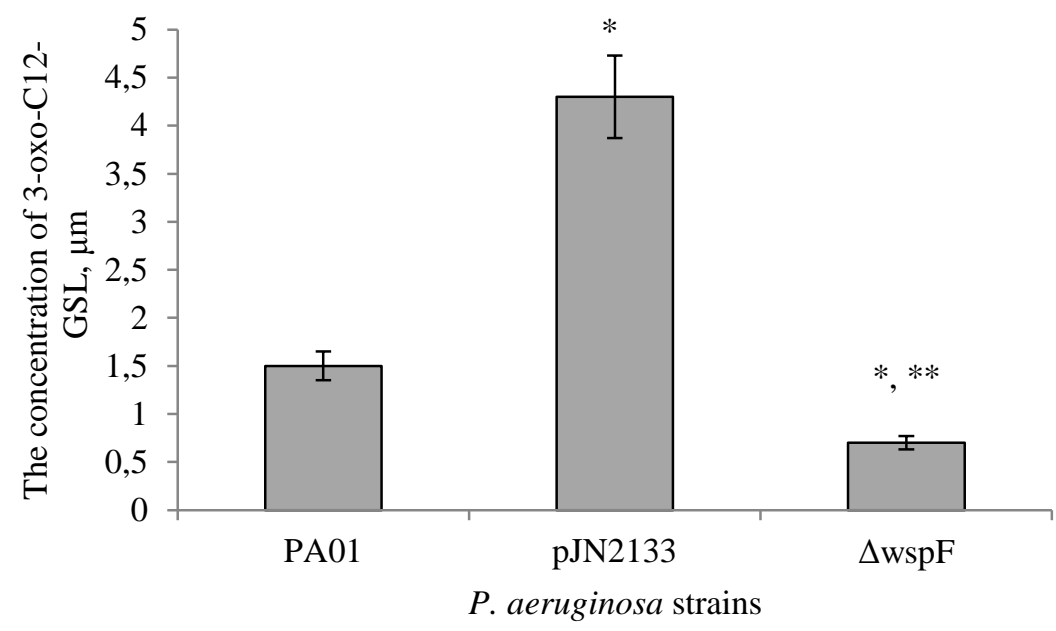

$a$

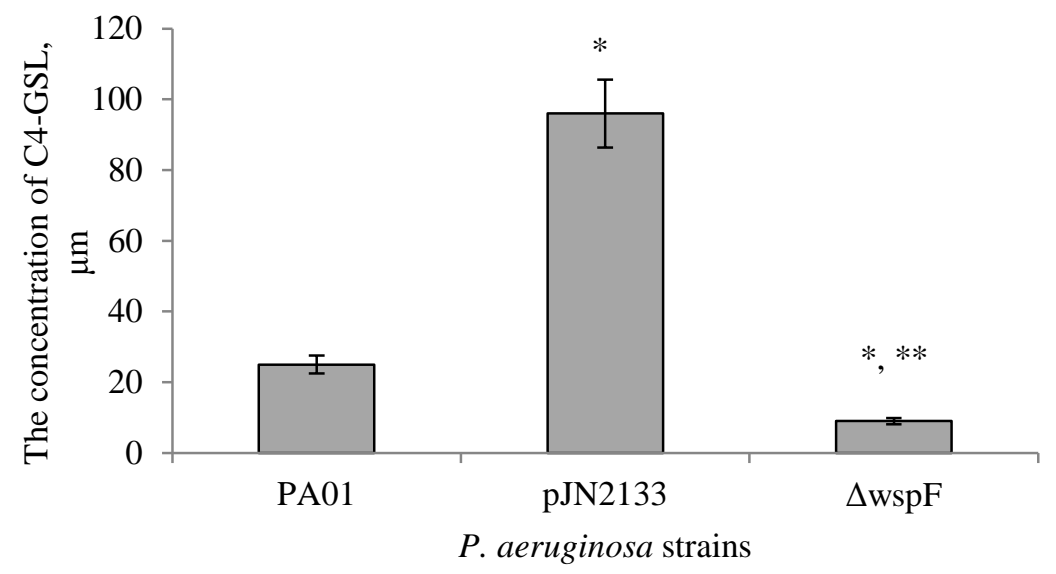

$b$

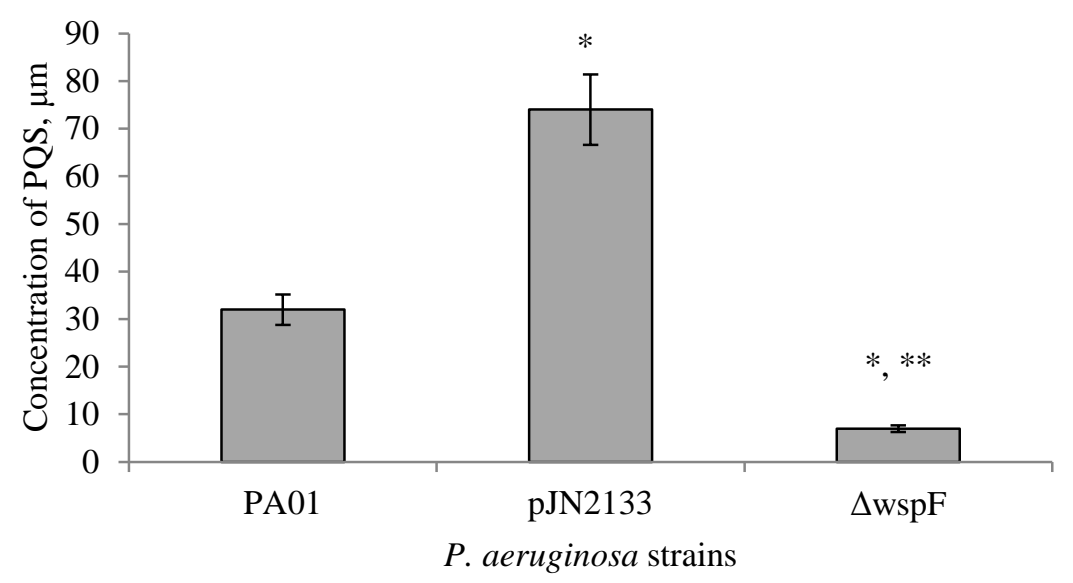

$c$

Fig. 2. The level of QS autoinducers in the supernatants of biofilm cultures of the studied strains of $P$. aeruginosa: $a$ - the concentration of 3-oxo-C12-HSL; $b$ - concentration of C4-HSL; $c$ - PQS concentration;

* - the difference is significant in comparison with strain PA01 $(\mathrm{p} \leq 0.01)$;

** - the difference is significant compared to strain pJN2133 $(\mathrm{p} \leq 0,001)$ 
Against the background of low levels of cyclic-diGMP strain $P$. aeruginosa PA01 pJN2133 synthesizes in biofilm culture an increased number of major autoinducers QS compared to P. aeruginosa PA01: 2.9 times 3oxo-C12-HSL, 3.8 times C4-HSL and 2.3 times PQS. Under the same conditions, the cultivation of $P$. aeruginosa PA01 $\Delta w s p F$, characterized by an increased content of cyclic-di-GMP, produces significantly fewer of these signalling molecules: 2.1 times 3-oxo-C12-HSL, 2.8 times C4-HSL and 4.6 times PQS. Comparison of mutant strains indicates that $P$. aeruginosa PA01 pJN2133 in the synthesis of autoinducers QS: 3-oxo-C12-HSL, C4-HSL and PQS is dominated by $P$. aeruginosa PA01 $\Delta w s p F$ in $6.1 ; 5.4$ and 11.4 times, respectively.

\section{Discussion of research results}

Thus, when cultured in biofilm cultures, $P$. aeruginosa cells with low cyclic-di-GMP content produce more autoinducers of the three main links of the intercellular communication system than cells of the parent strain and, in particular, the strain with elevated levels of the secondary messenger. These results coincide with the data of other authors who, using transcriptome analysis, showed an increase in the expression of rhl and pqs operons in another mutant $P$. aeruginosa with low levels of cyclic-di-GMP [22]. Given that mutants with a low content of the secondary messenger form a biofilm with a broken architecture, it is possible to propose a strategy to combat biofilm infections aimed at reducing the level of the secondary messenger. If such substances can be found, they will become an important alternative to modern antimicrobial agents, to which bacteria in biofilms are virtually insensitive $[23,24]$. In the early stages of the study of the QS in Pseudomonas, it was believed that the activation of its rhl and pqs systems, which is accompanied by an increase in the synthesis of the corresponding autoinducers, promotes the formation of biofilms [12, 13]. Our results do not fully agree with this opinion. It can be assumed that cyclic-di-GMP makes a more important contribution to the regulation of biofilm formation. According to a number of authors, the role of QS is to regulate the synthesis of exoDNA, which stabilizes biofilms $(r h l)$, and polysaccharides of their matrix. In addition, this system is responsible for the synthesis of numerous exoproducts, in particular, rhamnolipids, which are effective biosurfactants and are involved in maintaining the architecture of biofilms [25, 26]. In general, it should be noted that the mechanisms of interaction of the two regulatory systems: cyclic-di-GMP and QS, have not been definitively resolved. The relevance of further research is due to two facts. On the one hand, some secondary metabolites of the QS system, the synthesis of which is affected by the secondary messenger, are factors in the pathogenicity of $P$. aeruginosa. On the other hand, a number of these secondary metabolites are potentially useful biotechnological products, in particular, exoenzymes, pyocyanin, rhamnolipids. Earlier we found that the introduction of exogenous synthetic PQS in the culture of $P$. aeruginosa PA01 increases the synthesis of biosurfactants and changes the ratio of mono- and dirhamnolipids [27]. Therefore, in the future it is planned to determine the ability of the studied strains to biosynthesis of such products.

Study limitations. The limitation of the study is the use of only three strains of $P$. aeruginosa, which makes it impossible to consider the established relationships between the studied parameters inherent in all members of this species. It is necessary to expand the range of strains due to other collection, clinical and selected from natural ecological niche samples.

Prospect for further research. The study will help deepen knowledge about the relationship between the two signalling systems of bacterial cells. Determining the dependence of the biosynthesis of secondary metabolites controlled by the QS system on the content of cyclic-di-GMP will make it possible to develop ways to regulate these processes - to inhibit in case of infections and stimulate in case of biotechnologically useful products.

\section{Conclusions}

There is a directly proportional relationship between the intracellular content of cyclic-di-GMP and the ability to form a biofilm. The $P$. aeruginosa strain with an increased level of secondary messenger forms the strongest biofilm, the weight of which is 1.33 and 5 times greater than the wild-type strain and the strain with a low content of cyclic-di-GMP.

The concentration of QS autoinducers in the medium is inversely related to the intracellular content of cyclic-di-GMP: compared to the parent strain, it is increased in the strain with a low content of the secondary messenger and decreased in the strain with its increased level.

\section{Conflict of interests}

Authors declare no conflict of interests.

\section{Gratitude}

The study was conducted with the financial support of the Ministry of Education and Science of Ukraine and Erasmus+ grants. The authors are sincerely grateful to Dr. Madeleine Ramstedt for the opportunity to conduct part of the experimental research in the Department of Chemistry at the University of Umeå, Sweden.

\section{References}

1. Bjarnsholt, T., Jensen, P. O., Fiandaca, M. J., Pedersen, J., Hansen, C. R., Andersen, C. B. et. al. (2009). Pseudomonas aeruginosabiofilms in the respiratory tract of cystic fibrosis patients. Pediatric Pulmonology, 44 (6), 547-558. doi: http://doi.org/10.1002/ppul.21011

2. Gellatly, S. L., Hancock, R. E. W. (2013). Pseudomonas aeruginosa: new insights into pathogenesis and host defenses. Pathogens and Disease, 67 (3), 159-173. doi: http://doi.org/10.1111/2049-632x.12033

3. Sadikot, R., Bedi, B., Maurice, N. (2018). Microarchitecture of Pseudomonas aeruginosa biofilms: A biological perspective. Biomedical and Biotechnology Research Journal, 2 (4), 227-236. doi: http://doi.org/10.4103/bbrj.bbrj_98_18

4. Ha, D.-G., O'Toole, G. A. (2015). C-di-GMP and its Effects on Biofilm Formation and Dispersion: a Pseudomonas Aeruginosa Review. Microbial Biofilms, 301-317. doi: http://doi.org/10.1128/9781555817466.ch15

5. Valentini, M., Filloux, A. (2016). Biofilms and Cyclic di-GMP (c-di-GMP) Signaling: Lessons fromPseudomonas aeruginosaand Other Bacteria. Journal of Biological Chemistry, 291 (24), 12547-12555. doi: http://doi.org/10.1074/jbc.r115.711507

6. Simm, R., Morr, M., Kader, A., Nimtz, M., Römling, U. (2004). GGDEF and EAL domains inversely regulate cyclic diGMP levels and transition from sessility to motility. Molecular Microbiology, 53 (4), 1123-1134. doi: http://doi.org/10.1111/j.13652958.2004.04206.x 
7. Romling, U., Galperin, M. Y., Gomelsky, M. (2013). Cyclic di-GMP: the First 25 Years of a Universal Bacterial Second Messenger. Microbiology and Molecular Biology Reviews, 77 (1), 1-52. doi: http://doi.org/10.1128/mmbr.00043-12

8. Seshasayee, A. S. N., Fraser, G. M., Luscombe, N. M. (2010). Comparative genomics of cyclic-di-GMP signalling in bacteria: post-translational regulation and catalytic activity. Nucleic Acids Research, 38 (18), 5970-5981. doi: http://doi.org/10.1093/nar/gkq382

9. Hickman, J. W., Tifrea, D. F., Harwood, C. S. (2005). A chemosensory system that regulates biofilm formation through modulation of cyclic diguanylate levels. Proceedings of the National Academy of Sciences, 102 (40), 14422-14427. doi: http://doi.org/10.1073/pnas.0507170102

10. Lee, J., Zhang, L. (2014). The hierarchy quorum sensing network in Pseudomonas aeruginosa. Protein \& Cell, 6 (1), $26-41$. doi: http://doi.org/10.1007/s13238-014-0100-x

11. Bjarnsholt, T., Tolker-Nielsen, T., Hoiby, N., Givskov, M. (2010). Interference of Pseudomonas aeruginosa signalling and biofilm formation for infection control. Expert Reviews in Molecular Medicine, 12. doi: http://doi.org/10.1017/s1462399410001420

12. Pearson, J. P., Gray, K. M., Passador, L., Tucker, K. D., Eberhard, A., Iglewski, B. H., Greenberg, E. P. (1994). Structure of the autoinducer required for expression of Pseudomonas aeruginosa virulence genes. Proceedings of the National Academy of Sciences, 91 (1), 197-201. doi: http://doi.org/10.1073/pnas.91.1.197

13. Pesci, E. C., Milbank, J. B. J., Pearson, J. P., McKnight, S., Kende, A. S., Greenberg, E. P., Iglewski, B. H. (1999). Quinolone signaling in the cell-to-cell communication system of Pseudomonas aeruginosa. Proceedings of the National Academy of Sciences, 96 (20), 11229-11234. doi: http://doi.org/10.1073/pnas.96.20.11229

14. Yang, L., Nilsson, M., Gjermansen, M., Givskov, M., Tolker-Nielsen, T. (2009). Pyoverdine and PQS mediated subpopulation interactions involved in Pseudomonas aeruginosa biofilm formation. Molecular Microbiology, 74 (6), 1380-1392. doi: http://doi.org/10.1111/j.1365-2958.2009.06934.x

15. Barken, K. B., Pamp, S. J., Yang, L., Gjermansen, M., Bertrand, J. J., Klausen, M. et. al. (2008). Roles of type IV pili, flagellum-mediated motility and extracellular DNA in the formation of mature multicellular structures in Pseudomonas aeruginosa biofilms. Environmental Microbiology, 10 (9), 2331-2343. doi: http://doi.org/10.1111/j.1462-2920.2008.01658.x

16. Christensen, G. D., Simpson, W. A., Younger, J. J., Baddour, L. M., Barrett, F. F., Melton, D. M., Beachey, E. H. (1985). Adherence of coagulase-negative staphylococci to plastic tissue culture plates: a quantitative model for the adherence of staphylococci to medical devices. Journal of Clinical Microbiology, 22 (6), 996-1006. doi: http://doi.org/10.1128/jcm.22.6.996-1006.1985

17. Cataldi, T. R. I., Bianco, G., Frommberger, M., Schmitt-Kopplin, P. (2004). Direct analysis of selectedN-acyl-Lhomoserine lactones by gas chromatography/mass spectrometry. Rapid Communications in Mass Spectrometry, 18 (12), $1341-1344$. doi: http://doi.org/10.1002/rcm.1480

18. Palmer, G. C., Schertzer, J. W., Mashburn-Warren, L., Whiteley, M. (2010). Quantifying Pseudomonas aeruginosa Quinolones and Examining Their Interactions with Lipids. Quorum Sensing, 207-217. doi: http://doi.org/10.1007/978-1-60761-971-0_15

19. Rybtke, M. T., Borlee, B. R., Murakami, K., Irie, Y., Hentzer, M., Nielsen, T. E. et. al. (2012). Fluorescence-Based Reporter for Gauging Cyclic Di-GMP Levels in Pseudomonas aeruginosa. Applied and Environmental Microbiology, 78 (15), 5060-5069. doi: http://doi.org/10.1128/aem.00414-12

20. Lapach, S. N., Chubenko, A. V., Babych, P. N. (2001). Statystycheskye metodы v medyko-byolohycheskykh yssledovanyiakh s yspolzovanyem Excel. Kyiv: Moryon, 260.

21. Halkin, M. B., Semenets, A. S., Finohenova, M. O., Halkin, B. M., Filipova, T. O. (2017). Biofilm formation and motility of bacteria Pseudomonas aeruginosa with different c-di- GMP level. Microbiology\&Biotechnology, 2 (38), 40-50. doi: http://doi.org/10.18524/2307-4663.2017.2(38).105020

22. Lin Chua, S., Liu, Y., Li, Y., Jun Ting, H., Kohli, G. S., Cai, Z. et. al. (2017). Reduced Intracellular c-di-GMP Content Increases Expression of Quorum Sensing-Regulated Genes in Pseudomonas aeruginosa. Frontiers in Cellular and Infection Microbiology, 7. doi: http://doi.org/10.3389/fcimb.2017.00451

23. Turkina, M. V., Vikström, E. (2018). Bacteria-Host Crosstalk: Sensing of the Quorum in the Context of Pseudomonas aeruginosa Infections. Journal of Innate Immunity, 11 (3), 263-279. doi: http://doi.org/10.1159/000494069

24. Singh, S., Singh, S. K., Chowdhury, I., Singh, R. (2017). Understanding the Mechanism of Bacterial Biofilms Resistance to Antimicrobial Agents. The Open Microbiology Journal, 11 (1), 53-62. doi: http://doi.org/10.2174/1874285801711010053

25. Schuster, M., Peter Greenberg, E. (2006). A network of networks: Quorum-sensing gene regulation in Pseudomonas aeruginosa. International Journal of Medical Microbiology, 296 (2-3), 73-81. doi: http://doi.org/10.1016/j.ijmm.2006.01.036

26. Papenfort, K., Bassler, B. L. (2016). Quorum sensing signal-response systems in Gram-negative bacteria. Nature Reviews Microbiology, 14 (9), 576-588. doi: http://doi.org/10.1038/nrmicro.2016.89

27. Galkin, M. B., Mukhlis Abedalabas, I., Pachomova, E. Yu., Filipova, T. O. (2014). The effect of Pseudomonas aeruginosa signal quinolone on the rhamnolipids biosynthesis and rhamnosyltransferase 2 activity. European Scientific Journal, 3, 223-228.

Received date 18.02.2020

Accepted date 05.03.2020

Published date 30.04.2020

Mykola Galkin, PhD, Associate Professor, Department of Microbiology, Virology and Biotechnology, Odessa I. I. Mechnikov National University, Dvoryanska str., 2, Odessa, Ukraine, 65082

E-mail:kgalkin@onu.edu.ua

Anastasia Semenets, Junior Researcher, Biotechnology Science-Education Center, Odessa I. I. Mechnikov National University, Dvoryanska str., 2, Odessa, Ukraine, 65082

E-mail: assems@ukr.net

Boris Galkin, Doctor of Biological Science, Professor, Director of Center, Biotechnology Science-Education Center, Department of Microbiology, Virology and Biotechnology, Odessa I. I. Mechnikov National University, Dvoryanska str., 2, Odessa, Ukraine, 65082

E-mail: bgalkin@onu.edu.ua

Tetiana Filipova, Doctor of Biological Science, Professor, Head of Department, Department of Microbiology, Virology and Biotechnology, Odessa I. I. Mechnikov National University, Dvoryanska str., 2, Odessa, Ukraine, 65082 E-mail: tphilippova@ukr.net 